\title{
Differentiation-related proteins of the broad bean rust fungus Uromyces viciae-fabae, as revealed by high resolution two-dimensional polyacrylamide gel electrophoresis
}

\author{
H. Deising ${ }^{1}$, P. R. Jungblut ${ }^{2}$, and K. Mendgen ${ }^{1}$ \\ 1 Universität Konstan£, Fakultät für Biologie, Phytopathologie, Universitätsstrasse 10, W-7750 Konstanz, Federal Republic of Germany \\ 2 Freie Universitäı Berlił, Institut für Toxikologie und Embryonalpharmakologie, Garystrasse 5, W-1000 Berlin 33, \\ Federal Republic of Germany
}

Received July 30, 1990/Accepted October 29, 1990

\begin{abstract}
On artificial polyethylene membranes providing a thigmotropic signal, uredospores of the broad bean rust fungus Uromyces viciac-fabou differentiated a serics of infection structures which in nature are necessary to invade the host tissuc through the stomata. Within $24 \mathrm{~h}$ germ tubes, appressoria, substomatal vesicles, infection hyphae and haustorial mother cells were developed successively. Alterations in protein metabolism during infection structure differentiation of this obligate plant pathogen were analyzed in the absence of the host plant by high resolution two-dimensional polyacrylamide gel electrophoresis (2-DE) and silver staining. The norm pattern representing the 2-DE protein patterns of the whole developmental sequence of infection structures of $U$. viciae-fabae showed 733 spots. During infection structure differentiation 55 proteins were nowly formed, altered in quantity, or disappeared. Major alterations in the protein pattern occurred during uredospore gcrmination and when infection hyphae were formed. Uredospore germination was characterized by a decrease of acidic proteins and an increase mainly of proteins with isoelectric points ranging from weakly acidic to basic.
\end{abstract}

Key words: Infection. structure differentiation - Protein metabolism - Rust fungi - Thigmo-differentiation Two-dimensional polyacrylamide gel electrophoresis Uromyces viciae-fabae

While monokaryotic basidiospores of the majority of rust fungi, like many other plant pathogenic fungi, infect their host plant cells by direct penetration of cuticule and cell wall, dikaryotic uredospores differentiate a complex

Offrint requests to: $\mathrm{H}$. Deising

Abbreviations. 2-DE, two-dimensional polyacrylamide gel electrophoresis; DAPI, 4,6-diamino-phenylindol; kDa, kilo Dalton; $\mathrm{pl}$, isoclectic point; PMSF, phenylmetllylsulfonyl fluoride; SDSPAGE, sodium dodecyl sulfate polyacrylamide gel electrophoresis series of infection structures in order to invade the leaf through the stomata (Hoch and Staples 1987). The signal upon which germ tube growth ceases and infection structure differentiation is induced is provided by the surface topography (Wynn 1976; Hoch et al. 1987). When, in nature, the tip of the germ tube senses the stomatal lip of the guard cell formation of appressorium is induced (Hoch et al. 1987) and as a consequence substomatal vesicle, infection hypha and haustorial mother cell are serially differentiated within the host leaf or stem parenchyma (Mendgen et al. 1988).

The signal in nature effective in topography-induced differentiation (thigmodifferentiation), can be mimicked by artificial membranes like e.g. collodion membranes with oil inclusions (Dickinson 1949), polystyrene replicas of silicon rubber templates of the leaf surface (Wynn 1976) or scratched polyethylene sheets (Staples et al. 1983). Thus, using artificial membranes, development of infection structures of obligately biotrophic rust fungi can be analyzed physiologically, biochemically or at the molecular level in the absence of the host plant.

Huang and Staples (1982) and more recently Staples et al. (1986) have studied quantitative and qualitative changes in protein synthesis during the first $6 \mathrm{~h}$ after germination of uredospores of the bean rust fungus Uromyces appendiculatus under thigmo-inducing conditions. The experimental conditions used allowed the fungus to differentiate appressoria and substomatal vesicles. Huang and Staples (1982) used one-dimensional SDS-PAGE for protein scparation and reported on the synthesis of two proteins of 18.5 and $24 \mathrm{kDa}$ when appressoria were formed and a third protein of $23 \mathrm{kDa}$ when vesicles were synthesized. Separating a comparable sample by an improwed technique, i.e. two-dimensional polyacrylamide gel electrophoresis (2-DE) revealed that actually some 15 proteins were altered or newly formed during appressoria and vesicle differentiation in the bean rust fungus (Staples et al. 1986).

In this study, the protein patterns of sequentially formed infection structures of the broad bean rust fungus $U$. viciae-fabae were analyzed by high resolution $2-\mathrm{DE}$ 
and sensitive silver staining. In contrast to $U$. appendiculatus, the development of the broad bean rust fungus proceeded to the stage of haustorial mother cells on artificial membranes. Thus, alterations in the protein pattern at developmental stages which occur immediately prior to the establishment of biotrophy were analyzed for the first time. Silver staining, though somewhat less sensitive as compared with ${ }^{35} \mathrm{~S}$-labeling was used because il also allows the detection of proteins which are present in spores and are degraded during infection structure differentiation or those proteins which are exclusively posttranslationally altercd.

Based on the analyses and results reported here, differentiation-related proteins which occur immediately prior to establishment of biotrophy and thus are possibly essential in pathogenesis, can be identified by a combination of two-dimensional electrophoresis and microsequence analysis or amino acid composition analysis (Eckerskorn et al. 1988).

\section{Materials and methods}

\section{Organism}

The uredinial culture of Uromyces viciae-fabae (Pers.) Schroet. was from a one-spore-line initiated from naturally infected Vicia faba plants collected in Konstanz, FRG. Uredospores were produced on Vicia faba cv con amore in growth chambers at a $16 \mathrm{~h}: 8 \mathrm{~h}$ light: dark regime and $22^{\circ} \mathrm{C}$.

\section{Differentiation of infection structures}

Approximately $150 \mathrm{mg} U$. viciae-fabae uredospores were dustcd onto a $1870 \mathrm{~cm}^{2}$ polyethylene membrane. To induce thigmodifferentiation membranes had been scratched with brass brushes. When germ tube proteins were to be analyzed smooth polyethylene sheets (no thigmotropic signal) were used. After inoculation membranes were misted with distilled $\mathrm{H}_{2} \mathrm{O}$ (4 $\mathrm{ml}$ per membrane) and incubated in darkness at $19^{\circ} \mathrm{C}$ at $100 \%$ relative humidity.

Non-differentiated uredosporelings (germ tubes) were harvested $6 \mathrm{~h}$ after jnoculation from non-inductive membranes. Structures which had developod appressoria, vesicles, infection hyphae or haustorial mother cells were harvestcd $7,9,18$, and $24 \mathrm{~h}$ after inoculation from scratched polyethylene sheets.

Io prepare spore protein extracts spores were homogenized without previous inoculation of membranes.

\section{Protein extraction}

Fungal spores, germ tubes and infection structures at various stages of development as indicated above were homogenized in $50 \mathrm{mM}$ Tris-HCl, $\mathrm{pH} 8.6$, containing $2 \%(\mathrm{w} / \mathrm{v}) \mathrm{Na}$-deoxycholate, $0.03 \%$ (w/w) SDS, $4 \mathrm{mM}$-mercaptoethanol, $1 \mathrm{mM} \mathrm{PMSF}$, and $0.5 \%$ (v/v) methanol by pistil and mortar at 4 C. Acid washed quartz crystals were added to aid ceil disruption. After centrifugation at $30000 \mathrm{~g}$ at $2^{\circ} \mathrm{C}$ for $25 \mathrm{~min}$ the supernatant was adjusted to contain $90 \%(\mathrm{v} / \mathrm{v})$ ethanol and incubated at $-20^{\circ} \mathrm{C}$ overnight. Precipitated proteins were centrifuged as described above. After washing the pellet with $90 \%(\mathrm{v} / \mathrm{v})$ ethanol $\left(-20^{\circ} \mathrm{C}\right)$ twice the proteins were redissolved in $10 \mathrm{mM}$ Tris- $\mathrm{HCl}, \mathrm{pH} 8.8$, containing $10 \%$ (v/v) glycerol.

\section{Protein determination}

Protcin detcrmination was based on the method of Bradford (1976). A commercial protein assay solution (Bio Rad) and $\gamma$-globulin as a standard were used.

\section{Two-dimensional polyacrylamide gel electrophoresis and silver staining of the separated proteins}

Two-dimensional electrophoresis combining isoelectric focusing and SDS-PAGE as described by Klose (1975) and modified by Jungblut and Seifert (1990) was used to separate proteins of Uromyces spores, germ tubes and differentiated infection structures. Before 2-DE the samples were adjusted to contain $9 \mathrm{M}$ urea, $5 \%(v / v) \beta$-mercaptoethanol and $2 \%(w / v)$ ampholyte. Using an ampholyte compo sition of one part Ampholine pH 3.5-10 (Pharmacia/LKB, Freiburg, FRG), one part Servalyt pH 2-11 (Serva, Heidelberg, FRG), three parts Pharmalyte $\mathrm{pH} 4-6.5$ (Pharmacia/LKB), two parts Pharmalyte $\mathrm{pH} 5-8$ and onte part Pharmalyte $\mathrm{pH} 6.5-9$ and a final conecnlration of $2 \%(w / v)$ ampholytes the resolution of $U$. viciae-fabae proteins could be further improved compared to the ampholyte composition described by Jungblut and Seifert (1990). Samples contaiming $45 \mu \mathrm{g}$ protein were applied at the anodic side of the gels.

For the second dimension $15 \%$ (w/v) acrylamide gels ( $T=$ $15.2 \%, C=1.3 \%$ ) were used. The gel size was 6.5 (running direction) $\times 8.3 \times 0.15 \mathrm{~cm}$. Molecular weight and pl calibration was performed with marker proteins as described by Jungblut and Seifert (1990). Proteins were detected with the penetrating silver staining method described by Jungblut and Seifert (1990).

\section{Evaluation of two-dimensional electrophoresis patterns}

The protein patterns obtained were compared visually as described by Jungblut and Klose (1986). Differences greater than $45 \%$ relative to the higher value are detected reproducibly by this method (Jungblut ct al. 1985). The proteins of three preparations of spores and of each differentiation step were separated by 2-DE. The 2-DE paltern of cach developmental stage was compared with the 2-DE pattern of the following stage. As the spot composition of the protein patterns was similar, most of the spols served as internal marker proteins for the comparison. Only differences occuring in all three preparations were accepted as differentiation-rclated altcrations. To avoid subjective interpretations two experienced investigators looked for differences independently, and only differences detected by both investigators were accepted.

A notm patterin of $U$. viciae-fabae proteins was obtained from three 2-DF patterns of three spore preparations. Each spot visually detectable was drawn on a transparent foil overlaid on a $18 \times 24 \mathrm{~cm}$ photography of the gel investigated. In this way each of the two investigators drew a 2-DF pattern of each of the three spore preparations. First, a pre-norm paticrn of each preparation was obtained by matching the two protein patterns of each person. Then the three pre-norm patterns were matched. The matchings were performed with the criterion that only those proteins were acceptcd as spore proteins occuring in all protein patterns. Additional spots occuring during rust infection structure differentiation up to haustorial mother cell formation were inserted into the sporc norm pattern. Therefore, the resulting norm pattern represents a norm paltern of the whole developmental sequence of infcction structures of $U$. viciae-fabae.

\section{Staining and light microscopy}

Microscopical techniques essentially followed the description of Freytag et al. (1988). For fluorescence microscopy, samples were 

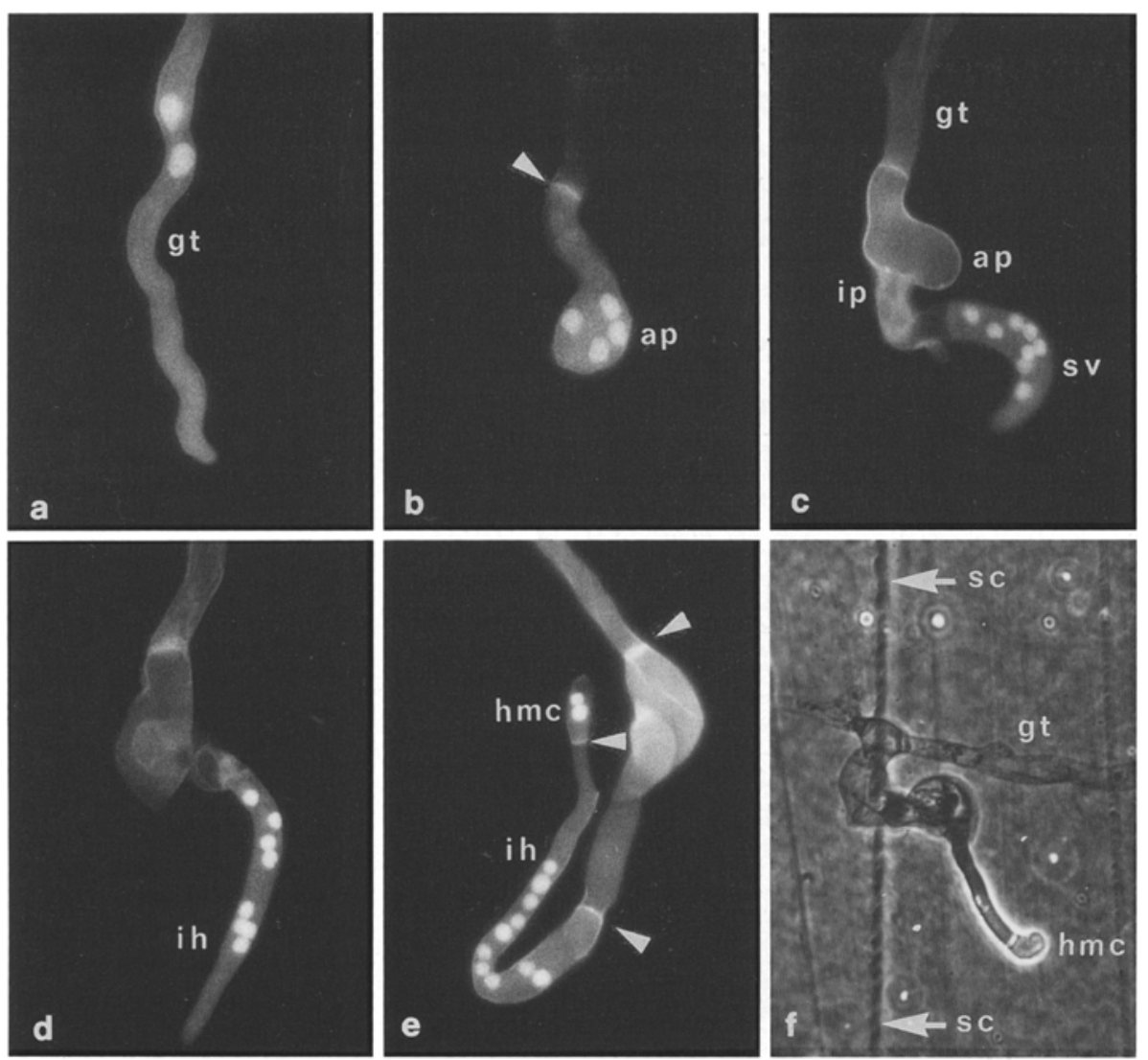

Fig. 1a-f. Micrographs of uredospore infection structures of Uromyces viciaefabae. Germ tube (a), appressorium (b), substomatal vesicle (c), infection hypha (d) and ha ustorial mother cell (e) are differentiated sequentially. Nuclear conditions of infection structures are demonstrated by fluorescence microscopy after DAPICalcofluor staining $(a-c)$. $\Lambda$ series of infection structures was aliernatively stained with trypan blue in lactophenol-glycerol to show a scratch on the polycthylene membranc inducing infeetion structure differentiation (f). $a p$, appressorium; $g t$, germ tube; $h m c$, haustorial mother cell; $h$, infection hypha; ip. infection peg; $s c$, scratch; $s v$, substomatal vesicle. Septa are indicated by arrowheads fixed in $0.5 \%$ glutaraldehyde for 30 min and subsequently stained with DAPI for $5 \mathrm{~min}$ and with Calcofluor for $4 \mathrm{~min}$. A Zeiss standard incident fluorescence microscope with a 356-nm excitalion filter and 420 -nm barriet filter was used. Differential-interferencecontrast microscopy was performed after staining with $0.1 \%(\mathrm{w} / \mathrm{v})$ trypan blue in lactophenol : glycerol: $\mathrm{H}_{2} \mathrm{O}(1: 1: 1)$.

\section{Results}

Sequential differentiation of rust infecion structures on artificial membranes

Under appropriate conditions Uromyces viciae-fabae uredospores differentiated a series of infection structures on artificial membranes such as scratched polyethylene sheets. The germ tube (Fig. 1 a) clongated until a signal on the membrane similar to that provided by the stomatal topography was perceived. Germ tube growth ceesed and appressorium development which was accompanied by division of the two germ tube nuclei was initiated and a septum between appressorium and germ tube was produced (Fig. $1 b$, arrowhead). Next the infection peg on artificial membranes seen as a constriction between appressoria and vesicles - and, subsequently, the substomatal vesicle were formed (Fig. 1c). After migration of the cytoplasm into the vesicle the nuclei underwent a second round of mitotic division and a septum between vesicle and appressorium was formed. Nuclei and cytoplasm migrated into the infection hypha as it elongated (Fig. 1 d). Haustorial mother cells formed on artificial membranes contained between two and five nuclei and were clearly separated from the former structures by

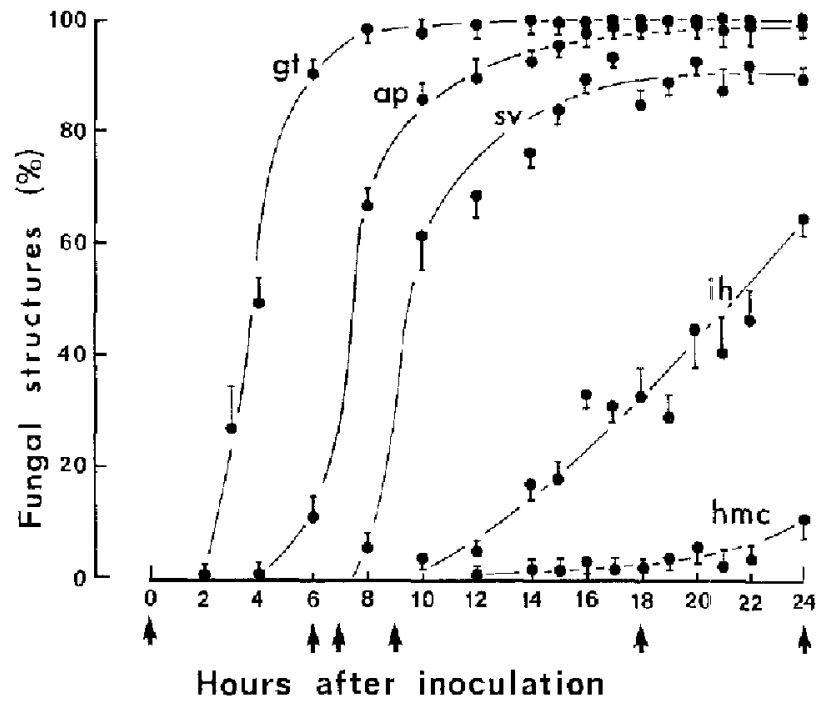

Fig. 2. Sequential differentiation of Uromyces viciae-jabae uredospore infection structures on artificial polyethylene membranes providing a thigmotropic signal. A minimum of 300 specimen per point of time was counted. Vertical bars represent mean deviations. $A r$ rows indicate protein extractions. Abbreviations are as in Fig. 1

another septum (Fig. 1e). Figure $1 \mathrm{f}$ shows a differentialinterference-contrast micrograph of trypan blue-stained infection structures. Appressorium formation had been induced by a scratch on the polyethylene membrane, resulting in differentiation of vesicle, infection hypha and haustorial mother cell. 

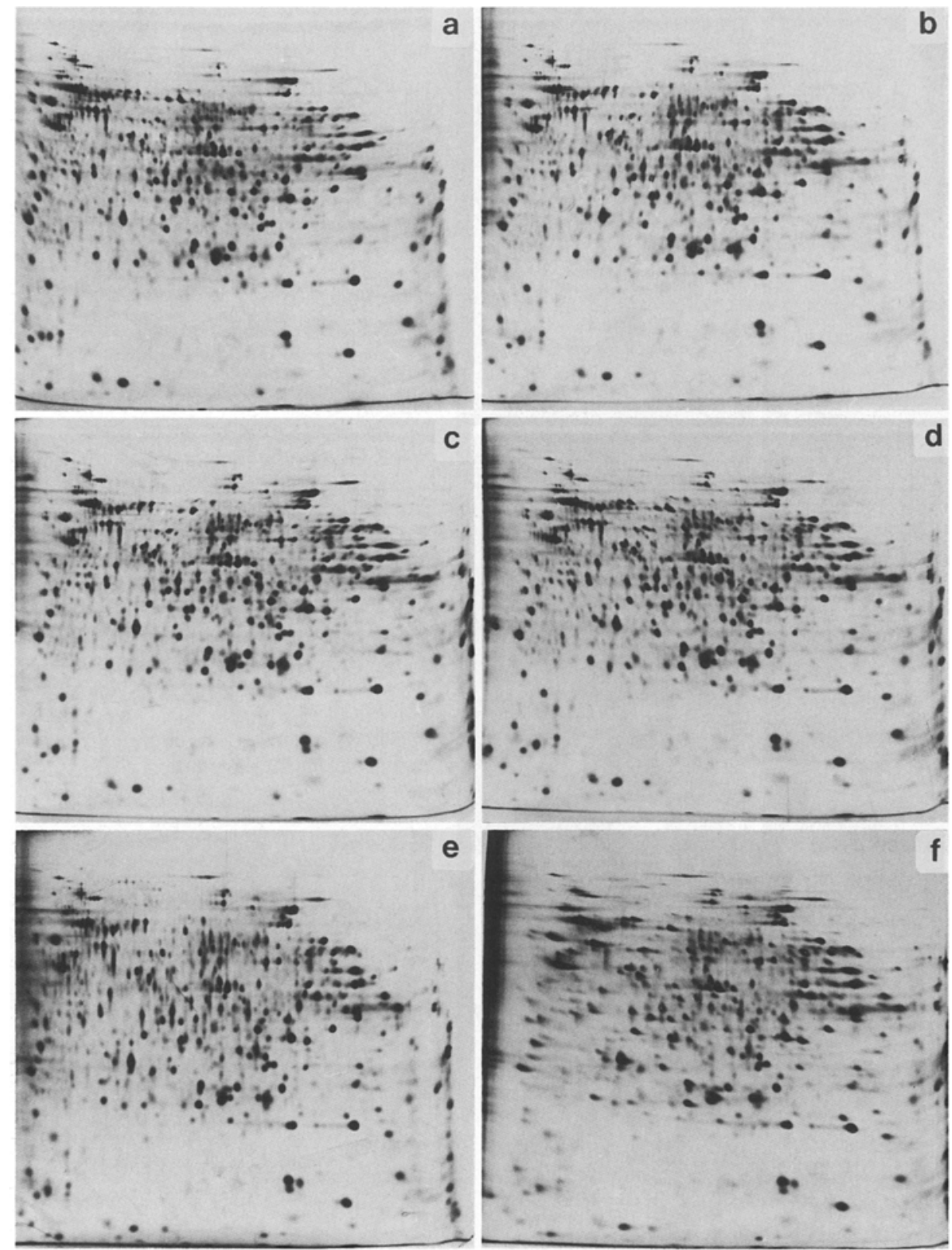

Fig. 3a-f. Two-dimensional protein palterns of tromyces viciaefabae uredospores (a), germ tubes (b) and infection structures differentiated for $7 \mathrm{~h}$ (c), $9 \mathrm{~h}$ (d), $18 \mathrm{~h}$ (c) and $24 \mathrm{~h}$ (f)
Under the experimental conditions used the series of rust infection structures occurred in a highly stable sequence (Fig. 2). Two hours after inoculation germ tubes began to form, and approximately $50 \%$ of the uredospores had germinated after $4 \mathrm{~b}$. At this time appressoria began to appcar. Seven hours after inoculation the beginning of vesicle formation was observed and infection hyphae were formed about $9 \mathrm{~h}$ after inoculation. Twelve hours after inoculation haustorial mother cells werc found even though only few specimen scemed to be capable to develop as far as that. While essentially all spores gave rise to germ tubes and appressoria, approximately $90 \%$ formed vesicles, $65 \%$ differentiated infection hyphae and little more than $10 \%$ developed haustorial mother cells within $24 \mathrm{~h}$. At the times indicated by arrows in Fig. 2, i.e. 0, 7, 9, 18 and $24 \mathrm{~h}$ after inoculation in the case of inducing membranes and $6 \mathrm{~h}$ after inoculation in the case of non-inducing membrancs samples were taken for 2-DE analyses. At these points of time a significant percentage of individuals had formed the respective structure and the subsequent structure was not found or as in the case of infection hyphae ( $18 \mathrm{~h}$ after inoculation) contributed less than $2 \%$ haustorial mother cells.

\section{Changes in the protein pattern}

during infection structure development

Figure 3 shows silver stained 2-DE gels of the six different developmental stages accessable in vitro. The high resolution gel system revealed 733 protein spots in extracts prepared from rust infection structures differentiated on 
Tablc 1. Quantitative alterations of differentiation-related proteins of Uromyces viciae-fabae uredospore infection structures. Protein patterns of sequentially doveloping infection structures were compared, and alterations were marked + if the protein was newly formed, - if it disappeared, $\uparrow$ if it was increased or $\downarrow$ if it was decreased in intensity. The numbers of the protein spots refer to the numbers given in Fig. 4

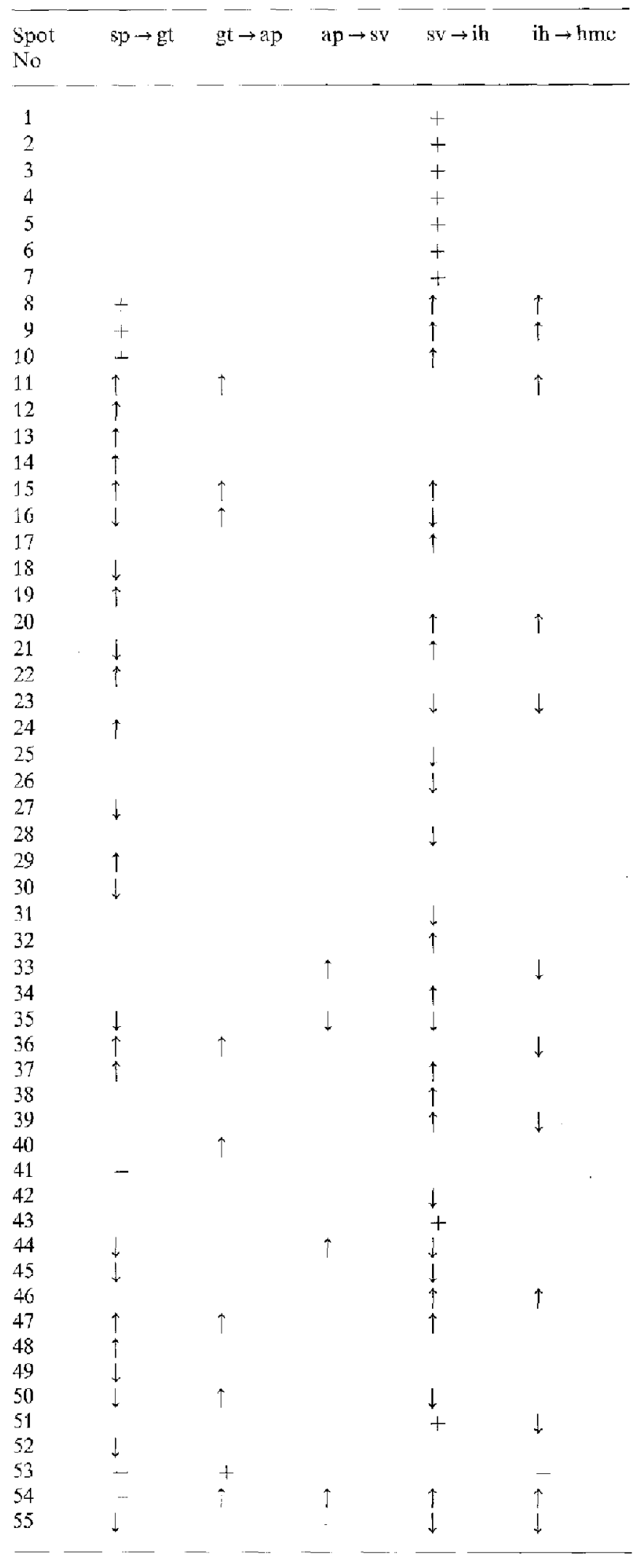

artificial membranes. Germination of $U$. viciae-fabae uredospores was accompanied by a significant quantitative increase of 13 proteins. In addition, four proteins were newly formed, two spots disappeared and 12 decreased in intensity (Figs. $3 \mathrm{a}, \mathrm{b}, 4$ and Table 1). Interestingly, most increasing and newly lormed protcins showed pIs ranging from weakly acidic to basic (e.g. spots number $8-15,19,22,29,36,47,48$ ); the ones that were down-shifted or disappeared during germination were acidic (c.g. spots number $16,30,41,44,45,49,50$, $52,55)$. Upon appressoria formation eight spots were increased. Again, most of them were rather basic proteins (e.g. spots number $11,15,40,47$ ) and thus extended the tendency mentioned to occur during germination. Three proteins were increased when vesicles were differentiated (spots number 33,44, 54 in Fig. 4 and Table 1) and one spot (number 35) was decrcased. More pronounced changes occurred when infection hyphae developed. While nine spots were newly formed and 15 increased significantly, 12 decrased. No correlations between upshifted or down-shifted spots and either molecular weight or $\mathrm{pl}$ of the proteins were obvious at this stage of diflerentiation (Figs. 3d, e, 4 and Table 1). Haustorial mother cell formation, however, resulted in lewer alterations of the protein pattern. Six spots were increased, six were decreased and one spot disappeared (spots number 8,9 , $11,20,23,33,36,39,46,51,53-55$ ). Interestingly, some proteins seemed to increase their concentration throughout the entire course of infection structure differentiation (spot number 54); others were altered only at developmental stages which are immediately prior to establishment of biotrophy (e.g. spots number $20,23,39,46,51$ ).

Table 2 summarizes the protein data of rust infection structure development. Two main developmental stages with major alterations of the protein pattern, i.e. germination and infection structure formation during which 31 and 36 changes were observed, are obvious. During appressoria and vesicle formation and when haustorial mother cells were differentiated fewer alterations occurred.

\section{Discussion}

Eukaryotic cells of diverged taxonomic origin sense and respond to surface signals (Carlile 1975; Dunn and Heath 1976), and especially rust fungi display a unique and precise response to signals provided by surface topography. Germ tube growth is oriented perpendicularly to ridges and furrows of leaves or artificial membranes (Hoch and Staples 1987). After sensing contact with the stomatal guard cell or a topographically similar structure on artificial membranes, rust fungi differentiate a sequence of infection structures ending with the haustorial mother cell. This developmental sequence in addition to the distinct morphological changes involves mitosis and gene expression (Staples and Huang 1981; Staples et al. 1986 ).

Significant effort has been made to analyze alterations of gene expression during rust infection structure differ- 


\section{Isoelectric point}

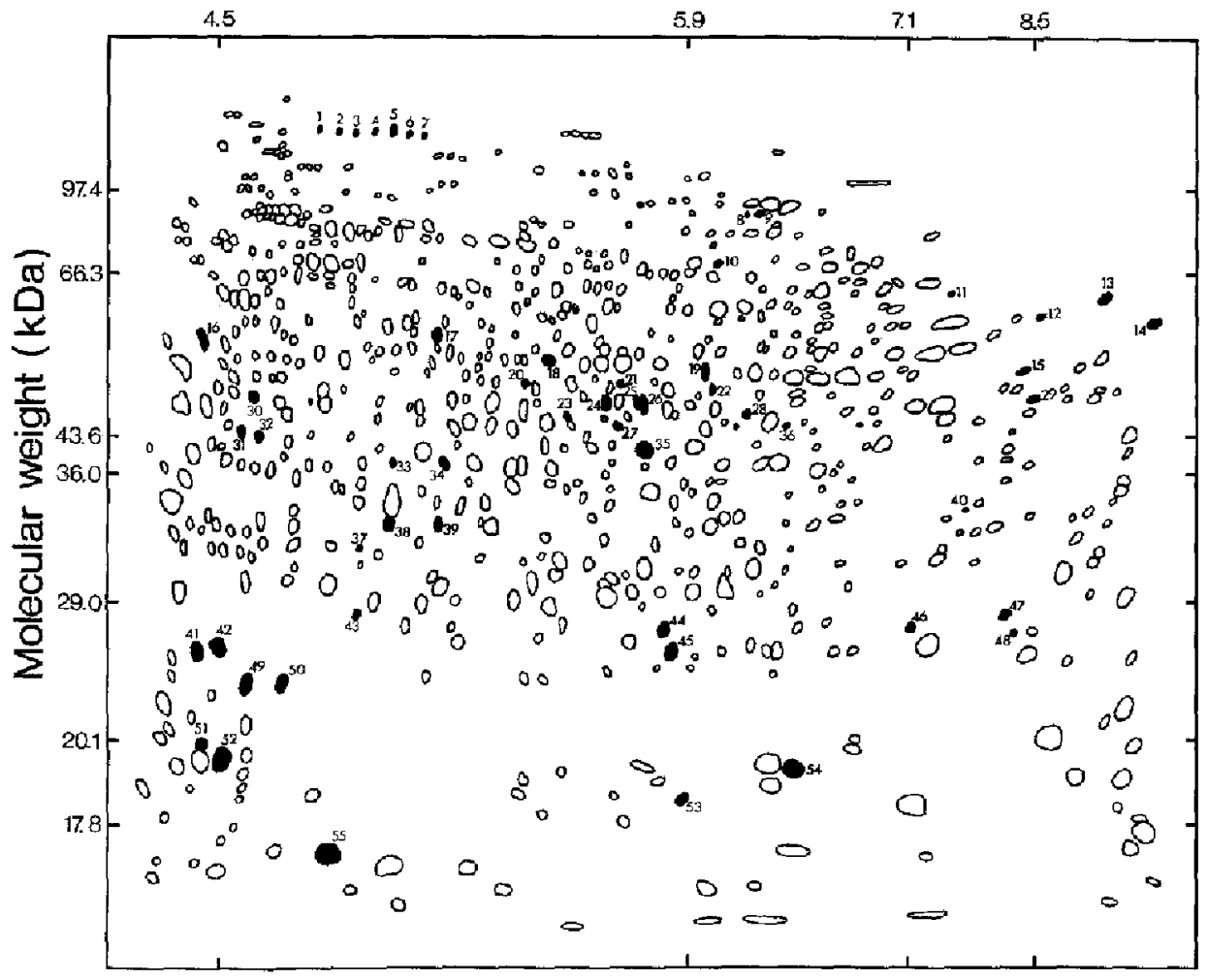

Fig. 4. Norm pattern of Uromyces viciae-fahae proteins. Protcins newly formed, altered in intensity or those disappeared during infection structure differentiation are drawn solid and are numbered. The numbers refer to the proteins listed in Table 1. Molecular weights (MW) and isoelectric points (pI) are given at the margins of the figure. Bovine carbonic anhydrase (29.0 kDa, pI 5.9) (Serva, Heidelberg, FRG), bovine setum albumine $(66.3 \mathrm{kDa})$, hotse myoglobin (17.8 kDa, pI 7.1), rabbil glyceraldehyde-3-phosphate dehydrogenase (36.0 kDa, pI 8.5), rabbit phosphorylase $b(97.4 \mathrm{kDa})$, soybean trypsin inhibitor (20.1 kDa, pr 4.5) (Sigma, Munich, FRG) and Escherichia coli aspartate aminotransferase $(43.6 \mathrm{kDa})$ (a kind gift of Dr. M. Herold, Basel, Switzerland) were used as $\mathrm{MW}$ - and pImatkers
Table 2. Summary of the alterations of the protcin paltern observed during Lromyces viciae-fabae uredospore infection structure differentiation. Alterations occurring during germination (sp $\rightarrow \mathrm{gt}$ ), appressorium (gt $\rightarrow$ ap), vesicle $(a p \rightarrow s v)$, infection hypha $(\mathrm{sv} \rightarrow \mathrm{ih}$ ) or haustorial mother cell formation (ih $\rightarrow \mathrm{hmc}$ ) are termed + or if a protein was newly formed or disappeared. $\uparrow$ or $\downarrow$ indicate an increasc or dectease in the intensity of a spot

\begin{tabular}{|c|c|c|c|c|}
\hline & + & - & $\uparrow$ & $\downarrow$ \\
\hline $\mathrm{sp} \rightarrow \mathrm{gt}$ & 4 & 2 & 13 & 12 \\
\hline $\mathrm{gt} \rightarrow \mathrm{ap}$ & 1 & & 8 & \\
\hline$a p \rightarrow s v$ & & & 3 & 1 \\
\hline$s v \rightarrow$ ih & 9 & & 15 & 12 \\
\hline ih $\rightarrow$ hmc & & 1 & 6 & 6 \\
\hline
\end{tabular}

entiation, using different rust species and different methods to induce infection structure formation.

The application of heat shock initiates infection structure differentiation (thermodifferentiation) in the wheat stem rust [ungus, Puccinia graminis f. sp. tritici. Kim et al. (1982) detected a total of 270 Coomassie Brilliant Blue-stainable proteins after: 2-DE; two proteins of 20 and $30 \mathrm{kD}$ i were only found in thermo-induced but not in non-induced cells. Similarly, Wanner et al. (1985) found two newly formed proteins of 21 and $35 \mathrm{kDa}$ after ${ }^{35} \mathrm{~S}-$ methionine pulse-labeling and one-dimensional SDSPAGE in thermodiflerentiated $P$. graminis.

The bean rust fungus Uromyces appendiculatus can be both thermo- and thigmo-induced to differentiate infection structures. Taking advantage of this feature Staples et al. (1989) compared polypeptides synthesized in re- sponse to thermo- and thigmoinduction. None of the 15 thigmodifferentiation-specific proteins was found in thermo-induced $U$. appendiculatus uredosporelings. However, studies on the mRNA level revealed that transcripts of two genes which are expressed stage-specifically in thigmo-differentiated bean rust uredosporelings also occur after thermo-differentiation and thus are development-specific (Bhairi et al. 1990). Contradictory results obtained on the protein- and mRNA-level suggest different translational regulatory mechanisms in thermo- and thigmo-differentiated rust fungi. Furthermore, deuterium oxide which selectively inhibits heat shock-induced differentiation but has no obvious effect on thigmodifferentiation of $U$. appendiculatus did not inhibit synthesis of six proteins as a response to thermoinduction. None of these proteins was found in thigmo-differcntiated uredosporelings (Staples et al. 1989). In the flax rust fungus Melampsora lini heat shock resulted in significant changes in the relative rate of ${ }^{35} \mathrm{~S}$-methionine incorporation into some 15 polypeptides (Shaw et al. 1985). This lungus, unlike $P$. graminis, does not form infection structures as a response to heat shock. Thus, rust lungi seem to be able to synthesize heat-shock proteins.

Taken together, these results suggest that thigmo- and thermoinduction affect protein metabolism of rust fungi in different ways. Reports on differentiation-related proteins of thermo-induced rust species should therefore be interpreted carefully.

The broad bean rust fungus $U$. viciae-fabae forms a series of infection structures on thigmo-inducing polyethylene sheets in a highly synchronized fashion. Proteins extracted from synchronized $U$. viciae-fabae infection structures at various time intervals after inoculation of 
polyethylene sheets as indicated in Fig. 2 were analyzed by $2-D E$ and silver staining. In contrast to studies involving $U$. appendiculatus, two main time periods of protein pattern alteration, i.e. uredospore germination and formation of infection hyphae were observed. Germ tube formation was accompanied by an increase of mainly basic and some weakly acidic and a decrease of acidic proteins. Since none of the 31 spots altered in intensity during germination has been identilied and functionally characterized we can only speculate that some of these basic proteins might be involved in tight adhesion to hycrohobic surfaces (Kunoh et al. 1991, and references therein) such as the cuticule in nature of polyethylene sheets in experiments performed in the absence of the host plant.

Staples et al. (1986) reported on 15 proteins, the rates of synthesis of which were altered during appressorium and vesicle formation in $U$. appendiculatus uredosporelings. Development of vesicle involved an upshift in the synthesis of several smaller $(14-28 \mathrm{kDa})$ and a downshift in the synthesis of proteins larger than $69 \mathrm{kDa}$. In $U$. viciae-fabae, however, alterations in the protein amount were found in 13 cases during appressorium and vesicle formation. During infection hypha differentiation nine proteins were newly formed, 15 spots were significantly increased, and 12 spots were decreased. Furthermore, haustorial mother cell formation was accompanicd by an increase of six and a decrease of six proteins; one spot disappeared at this stage of development. These later alterations occuring directly prior to the establishment of the parasitic phase of the host-parasite interaction have not been analyzed by Staples and co-workers since in their work only alterations occuring during appressorium and vesicle formation were investigated.

To improve our understanding of the interactions of rust fungi and their host plants it is desirable to identify and functionally characterize differentiation-rclated proteins, especially those occuring or disappearing during devclopmental stages immediately before biotrophy is established. As an alternative to a molecular approach in which stage-specific genes have been isolated (Bhairi et al. 1989), a combination of 2-DE and micro-sequence analysis or amino acid composition analysis could be useful to identify differentiation-related proteins. In contrast to cascade hybridization, analyses like those described here would also allow the detection of protcin alterations which are exclusively due to translational and post-translational modifications.

Acknowiedgements. We thank Ms. Anke Schaubitzer and MS. Annette Klink for excellent technical assistance, and the Deutsche Forschungsgemeinschaft (DFC) for grants to H.D. and K.M.

\section{References}

Bhairi SM, Staples RC, Freve P, Yoder OC (1989) Characterization of an infection structure-specific gene from the rust fungus Uromyes appendicalatus. Gene 81:237--243

Bhairi SM, Iacceti L. Staples RC (1990) Effect of heat shock on expression of thigmo-specific genes from a rust fungus. Exp Mycol 14:94-98
Bradford MM (1976) A rapid and sensitive method for the quantitation of microgram quantities of protein utilizing the principle of protein dye binding. Anal Biochem 72:248-254

Carlile M.T (1975) Taxes and tropisms: Diversity, biological signifieance and crolution. In: Carlile M.I (ed) Primitive sensory and communication systems. The laxes and tropisms of microorganisms and cells. Academic Press, Jondon New York, pp $1-28$

Dickinson S (1949) Studies in the physiology of obligate parasitism. II. The behaviour of the germ tubes of certain rusts in contact with various membranes. Ann Bot 13:219-236

Dunn GA, Heath JP (1976) A new hypothesis of contact guidance in tissue cells. Exp Cell Res 101:1-14

Eckerskorn C. Jungblut P, Mewes W, Klose J, Lottspeich F (1988) Identification of mouse brain proteins after two-dimensional electrophoresis and electroblotting by microsequence analysis and amino acid composition analysis. Electrophoresis $9: 830-$ 838

Freytag S, Bruscaglioni L, Gold RE, Mendgen K (1988) Basidiospores of rust fungi (Uromyces species) differentiate infection structures in vitro, Exp Mycol 12:275-283

Ioch $\mathrm{HC}$, Staples RC (1987) Structural and chemical ranges among the rust fungi during appressorium development. Annu Rev Phytopathol 25:231-247

Ioch HC, Staples RC, Whitehead B, Comeau J, Wolf ED (1987) Signaling for growth orientation and cell differentiation by surface topography in Uromyces. Science 235: 1659-1662

Huang B-F, Staples RC (1982) Synthesis of protems during differentiaton of the bean rust fungus. Exp Mycol 6:7-14

Jungblut PR, Klose I (1986) Composition and genetic variability of Heparin-Sepharose CL-6B protein fractions obtained from the solubilized proteins of mouse organs. Biochem Genet 24:925 939

Jungblut PR, Seifert R (1990) Analysis by high resolution twodimensional electrophoresis of differentiation-dependent alterations in cytosolic protein pattern of HL-60 leucemic cells. J Biochem Biophys Methods 21:47-58

Jungbiut PR, Schneider W, Klose J (1985) Quantitative analysis of two-dimensional electrophoretic protein patterns: Comparison of visual evaluation with computer-assisted evaluation. In: Neuhoff $V$ (ed) Electrophoresis '84. Verlag Chemie, Woinheim, pp $301-303$

Kim WK, IIowes NK, Rohringer R (1982) Detergent-solubie polypeptides in germinated uredospores and differentiated uredosporelings of wheat stem rust. Can J Plant Pathol 4:328333

Klose J (1975) Protein mapping by combined isoelectric focusing and elcetrophoresis of mouse tissue. A novel approach to testing for induced point mutations in mammals. Humangenetik $26: 231-243$

Kunoh H, Nicholson RL, Kobayashi I (1991) Extracelludar materials of lungal struet ures: Their signilicance at prepenetration stages of infection. In: Mendgen K, Lesemann DE (eds) Electronmierascopy of plant pathogens. Springer, Berlin Heidelberg New York, pp 223-234

Mendgen K, Schneider A, Sterk M, Fink W (1988) The differentiation of infection structures as a result of rccognition events between some biotrophic parasites and theit hosts. I Phytopathol $123: 259-272$

Shaw $M$, Boasson R, Scrubb L (1985) Effect of heat shock on protcin synthesis in flax rust uredosporeings. Can J Bot 63:20692076

Staples RC, Huang B-F (1981) Gene activation during differentiation of the rusts and anthracnose fungi. In: Turian $G$, Hohl HR (eds) The fungal spore: Morphogenetic controls. Academic Press, London New York, pp 335-353

Staples RC, Grambow IIJ, Foch HC, Wynn WK (1983) Contact with membrane grooves induces wheat stem rust uredospore germlings to differentiate appressotia but not vesisles. Phytopathology $73: 1436-1439$

Staples RC, Yoder OC, Hoch HC, Epstein I., Bhairi S (1986) Gene expression during infection strueture development by germlings 
of the rust fungi. In: Bailey JA (ed) Biology and molecular biology of plant-pathogen interactions. NATO ASI Series, vol H1. Springer, Berlin Heidelberg New York, pp 331-341

Staples RC, Hoch HC, Freve P, Bourett TM (1989) Heat shockinduced development of infection structures by bean rust uredospore germlings. Exp Mycol 13:149-157
Wanner R, Förster H, Mendgen K, Staples R (1985) Synthesis of differentiation-specific proteins in germlings of the wheat stem rust fungus after heat shock. Exp Mycol 9:279-283

Wynn WK (1976) Appressorium formation over stomates by the bean rust fungus: Response to a surface contact stimulus. Phytopathology 66:136-146 